\title{
SIMPLE AND COMPLEX COGNITIVE FUNCTIONS UNDER EXERTIONAL HEAT STRESS
}

\author{
Jelena Maric ${ }^{1}$, Milan Marjanovic ${ }^{1}$, Dalibor Jovanovic ${ }^{1}$, Filip Stojanovic ${ }^{1}$, Djordje Vukmirovic ${ }^{1}$, Vladimir Jakovljevic ${ }^{2}$ \\ ${ }^{1}$ Military Medical Academy, Belgrade, Serbia \\ ${ }^{2}$ Faculty of Medical Sciences, University of Kragujevac, Kragujevac, Serbia

\section{UTICAJ TOPLOTNOG STRESA I FIZIČKE AKTIVNOSTI NA KOGNITIVNE SPOSOBNOSTI

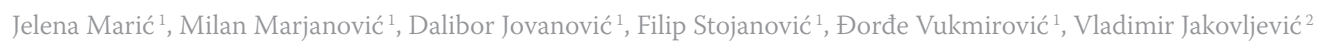 \\ Vojnomedicinska akademija, Beograd, Srbija \\ ${ }^{2}$ Fakultet medicinskih nauka, Univerzitet u Kragujevcu, Kragujevac, Srbija}

\section{ABSTRACT}

Heat stress is a significant problem in the military services. This study investigated the effects of exertional heat stress on cognitive performance.

Forty unacclimated male soldiers performed exertional heat stress tests in $\operatorname{cool}\left(20^{\circ} \mathrm{C}\right)$ and hot environments $\left(40^{\circ} \mathrm{C}\right)$. Cognitive performance was assessed using a computerized battery before and immediately after tests. Physical strain in cool conditions induced mild but significant deficits in accuracy in complex tests. The number of correct answers in the Matching to Sample Visual Search was reduced (92,18\% correct answers before vs. 88,64 after; $p<0,05)$ and also in the spatial part of the Pattern and Spatial Recognition Memory Test (85,25 vs. 8,75\%; $p<0,05)$. These decreases were more pronounced in hot conditions (92,38 vs. $84,31 \%$ in before and 84,21 vs. 73,42\% in the latter test; $p s<0,01$ and $<0,001$, respectively). Exertional heat stress also impaired more simple cognitive functions. A significant decrease in accuracy $(95,74$ vs. 93,89\%) and an increase in reaction time (300,32 vs. 315,00 ms) was observed in the Reaction Time test.

Strenuous physical activity in a hot environment induces mild cognitive deficits, especially in more complex tasks.

\section{SAŽETAK}

Toplotni stres predstavlja značajan problem u vojnoj službi. U ovom istraživanju se ispituje uticaj toplotnog stresa i fizičke aktivnosti na kognitivne sposobnosti.

40 neaklimatizovanih vojnika muškog pola podvrgnuto je testu toplotnog stresa i fizičkog napora u termoneutralnoj $\left(20^{\circ} \mathrm{C}\right)$ i toploj sredini $\left(40^{\circ} \mathrm{C}\right)$. Kognitivne funkcije su ispitivane kompjuterizovanom baterijom neposredno pre i nakon testa. U termoneutralnim uslovima, fizički napor je izazvao blagi pad preciznosti pri rešavanju složenih zadataka $u$ testu Matching to Sample Visual Search (92,18\% vs. 88,64; p<0,05), i prostornoj komponenti testa Pattern and Spatial Recognition Memory (85,25 vs. 78,75\%; p<0,05). Pad preciznosti je naglašeniji u toplim uslovima (92,38 vs. 84,31\%; $p<0,01$, odnosno 84,21 vs. 73,42\%; p<0,001), gde je, osim toga, došlo i do oštećenja jednostavnijih kognitivnih funkcija: $u$ testu Reaction Time zabeležen je pad preciznosti (95,74 vs. 93,89\%), kao i produženje vremena reakcije (300,32 vs. 315,00 ms).

Intenzivan fizički napor u toploj sredini dovodi do blagih kognitivnih deficita, pogotovo pri vršenju složenih zadataka.

\section{INTRODUCTION}

\section{2}

\section{ABBREVIATIONS}

CANTAB - Computerized Cognitive Attention Battery

EHS - Exertional Heat Stress

EHST - Exertional Heat Stress Test
HR - Heart Rate

Tty - Tympanic temperature

WBGT - Wet Bulb Globe Thermometer
Heat stress is a significant problem in the military services. Common preventive measures (e.g., restriction of physical activity, removal of clothing and moving into shade) are often impossible to achieve. Additional disadvantages include the burden of heavy equipment, ballistic vests, and other heavy items that must be worn during training and regular activities, and impermeable protective suits, which may inhibit evaporative cooling. Heat stress can impair physical and mental performance $(1,2)$. Studies of cognitive performance under hot conditions are 
difficult to evaluate because of variations in methodological design, exposure duration, skills and acclimation level. Human tolerance to heat stress also depends on fitness levels. Individuals with higher aerobic capacity show better adaptation to the combination of physical activity and hot environments (3).

Computerized batteries are applied to minimize bias in assessments of cognitive performance during physical exertion and/or heat stress $(4,5)$. CANTAB (computerized Cambridge Neuropsychological Test Automated Batteries) is a set of neuropsychological tests that are specifically designed for comparative assessments of cognition. The tests are graded in nature, with standardized feedback and a detailed recording of accuracy and speed.

Our study investigated the effects of strenuous physical activity in combination with a hot environment on cognitive performance in young fit male soldiers using computerized test batteries.

\section{SUBJECTS AND METHODS}

The participants were 40 male soldiers, aged $20 \pm 0,9$ years, with similar anthropometric and ergometric characteristics (Table 1). Subjects signed an informed consent form after a short briefing on the nature and purpose of the experiment. The Ethical Committee of the Military Medical Academy approved the experimental protocol. The procedures corresponded to international standards of thermal strain evaluation $(6,7)$. The subjects were randomly divided in two equal groups. The experimental group ( $\mathrm{H}$ group) performed the exertional heat stress test (EHST) in a hot environment (40 ${ }^{\circ} \mathrm{C}, 29{ }^{\circ} \mathrm{C}$ WBGT), and the control group (C group) performed the same test in a cool environment $\left(20^{\circ} \mathrm{C}, 16\right.$ ${ }^{\circ} \mathrm{C}$ WBGT). Trials were conducted in a climatic chamber in the Military Medical Academy, Institute of Hygiene, Department of Physiological Strain, during November and December 2011. Parameters of heat stress (tympanic temperatures and heart rates) were automatically monitored and recorded in real-time using a physiological data monitoring system (MP150SKT100C, BIOPAC Systems Inc., USA), and the Q4500 Exercise Test Monitor (Quinton Instruments, USA) respectively. The test and measurement protocols were described in detail in our previous studies $(8,9)$. Tests were limited to $90 \mathrm{~min}$ utes because of the temperature conditions and level of

Table 1. Anthropometric and ergometric parameters in both investigated groups

\begin{tabular}{|l|l|l|l|}
\hline & H & C & $p$ (H vs. C) \\
\hline Body height $(\mathrm{cm})$ & $180,63 \pm 5,71$ & $179,55 \pm 4,57$ & 0,595081 \\
\hline Body weight $(\mathrm{kg})$ & $74,85 \pm 9,66$ & $78,13 \pm 5,32$ & 0,656162 \\
\hline Body Mass Index $\left(\mathrm{kg} / \mathrm{m}^{2}\right)$ & $22,9 \pm 2,62$ & $24,29 \pm 1,95$ & 0,803931 \\
\hline Percentage of body fat $(\%)$ & $16,86 \pm 3,62$ & $17,06 \pm 4,47$ & 0,710612 \\
\hline $\mathrm{VO}_{2 \max }(\mathrm{ml} / \mathrm{min} / \mathrm{kg})$ & $59,55 \pm 10,64$ & $56,60 \pm 5,91$ & 0,235727 \\
\hline
\end{tabular}

$\mathrm{VO}_{2 \max }$ - Maximal oxygen consumption

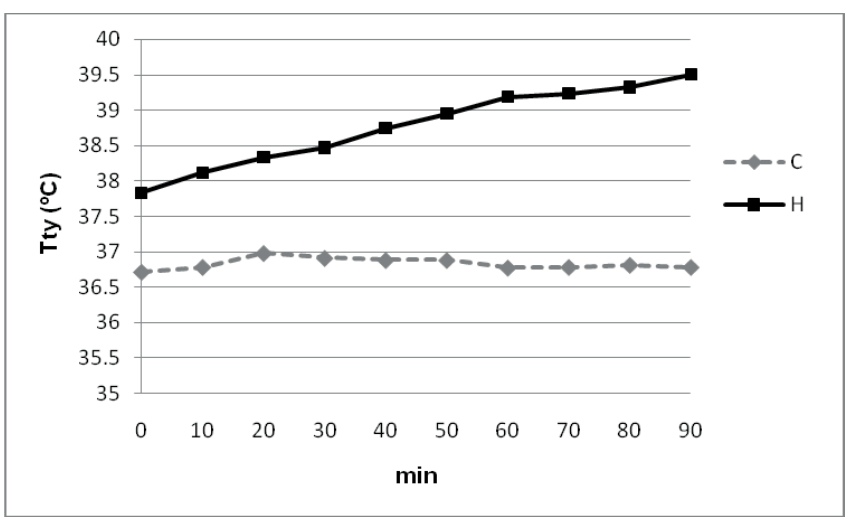

Figure 1. Average tympanic temperatures during the tests in both investigated groups

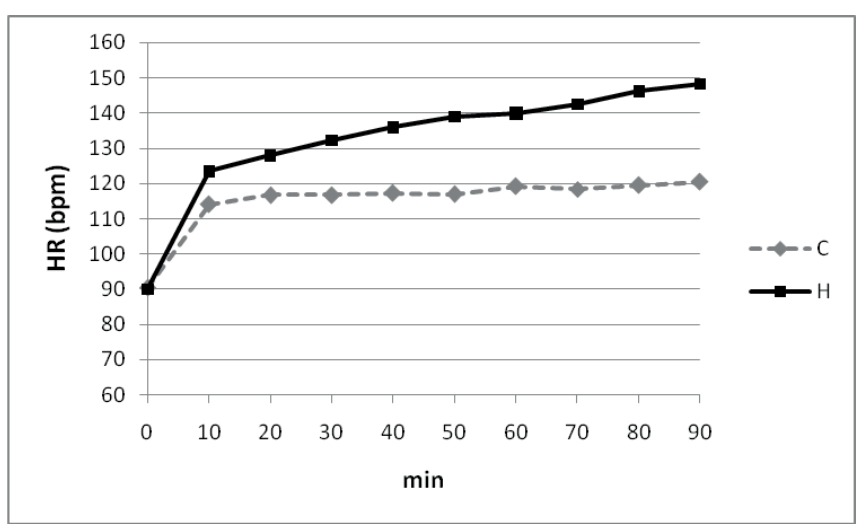

Figure 2. Average heart rates during the tests in both investigated groups

physical exertion. The following criteria were used for early termination: Tty $39,5{ }^{\circ} \mathrm{C}$, HR $190 \mathrm{bpm}$, or intolerable subjective discomfort. Cognitive performance was assessed using CANTAB, version 2,0, which consisted of 5 different tests that measure selective, divided, and sustained attention, information processing, working memory and recognition (10). Tests were administered using a computer with a touch-sensitive screen, and a response key was used for reaction timing. Cognitive examinations were administered to each soldier before and immediately after EHST, and each examination included the following tests: Motor Screening (MOT), Reaction Time (RTI), Matching to Sample Visual Search (MTS), and Pattern and Spatial Recognition Memory, which includes visual and spatial components (PSRp and PSRs). Accuracy (percentage of correct answers or number of errors) and speed in ms (reaction time, movement time, or attention time) were recorded for each test.

The Statistical Package for the Social Sciences (SPSS 20.0) was used to perform all statistical tests. Continuous variables are presented as means \pm standard deviation. Normal distribution was tested using the KolmogorovSmirnov test. Differences between performances before and after EHST were tested using repeated measures $t$ test. Significance was accepted at $p<0,05$. 
Table 2. Cognitive performance in both investigated groups

\begin{tabular}{|c|c|c|c|c|c|}
\hline \multirow[t]{2}{*}{ Test } & \multirow[t]{2}{*}{ Parameter } & \multicolumn{2}{|c|}{$\mathbf{H}$} & \multicolumn{2}{|c|}{$\mathrm{C}$} \\
\hline & & Before & After & Before & After \\
\hline \multirow[t]{2}{*}{ MOT } & $\begin{array}{l}\text { Latention } \\
\text { (ms) }\end{array}$ & $\begin{array}{l}525,00 \\
\pm 60,88\end{array}$ & $\begin{array}{c}624,37 \\
\pm 197,10\end{array}$ & $\begin{array}{l}560,00 \\
\pm 99,32\end{array}$ & $\begin{array}{r}625,15 \\
\pm 146,67\end{array}$ \\
\hline & $\begin{array}{l}\text { Errors } \\
(\mathrm{N})\end{array}$ & $\begin{array}{l}27,00 \\
\pm 7,17\end{array}$ & $\begin{array}{l}26,42 \\
\pm 8,19\end{array}$ & $\begin{array}{c}29,75 \\
\pm 13,52\end{array}$ & $\begin{array}{c}25,35 \\
\pm 11,76\end{array}$ \\
\hline \multirow[t]{3}{*}{ RTI } & $\begin{array}{l}\text { Correct answers } \\
(\%)\end{array}$ & $\begin{array}{l}95,74 \\
\pm 3,52\end{array}$ & $\begin{array}{c}93,89 \\
\pm 3,43 \%\end{array}$ & $\begin{array}{l}96,77 \\
\pm 3,59\end{array}$ & $\begin{array}{l}96,82 \\
\pm 3,04\end{array}$ \\
\hline & $\begin{array}{l}\text { Reaction time } \\
\text { (ms) }\end{array}$ & $\begin{array}{l}300,32 \\
\pm 31,53\end{array}$ & $\begin{array}{c}315,00 \\
\pm 33,77 *\end{array}$ & $\begin{array}{l}308,70 \\
\pm 50,15\end{array}$ & $\begin{array}{c}308,9 \\
\pm 35,52\end{array}$ \\
\hline & $\begin{array}{l}\text { Movement time } \\
(\mathrm{ms})\end{array}$ & $\begin{array}{c}367,42 \\
\pm 102,95\end{array}$ & $\begin{array}{c}373,21 \\
\pm 117,67\end{array}$ & $\begin{array}{c}400,20 \\
\pm 112,37\end{array}$ & $\begin{array}{r}394,25 \\
\pm 128,15\end{array}$ \\
\hline \multirow[t]{2}{*}{ MTS } & $\begin{array}{l}\text { Correct answers } \\
(\%)\end{array}$ & $\begin{array}{l}92,38 \\
\pm 4,90\end{array}$ & $\begin{array}{c}84,31 \\
\pm 9,51 *\end{array}$ & $\begin{array}{l}92,18 \\
\pm 5,14\end{array}$ & $\begin{array}{c}88,64 \\
\pm 6,95 \%\end{array}$ \\
\hline & $\begin{array}{l}\text { Latention } \\
(\mathrm{ms})\end{array}$ & $\begin{array}{l}1564,47 \\
\pm 507,41\end{array}$ & $\begin{array}{l}1694,89 \\
\pm 529,68\end{array}$ & $\begin{array}{l}1604,80 \\
\pm 526,77\end{array}$ & $\begin{array}{c}1579 \\
\pm 522,37\end{array}$ \\
\hline \multirow[t]{2}{*}{ PSRp } & $\begin{array}{l}\text { Correct answers } \\
(\%)\end{array}$ & $\begin{array}{l}90,56 \\
\pm 5,71\end{array}$ & $\begin{array}{l}87,94 \\
\pm 9,70\end{array}$ & $\begin{array}{r}93,54 \\
\pm 5,14\end{array}$ & $\begin{array}{l}90,98 \\
\pm 7,41\end{array}$ \\
\hline & $\begin{array}{l}\text { Latention } \\
(\mathrm{ms})\end{array}$ & $\begin{array}{l}1436,37 \\
\pm 287,91\end{array}$ & $\begin{array}{l}1371,42 \\
\pm 312,63\end{array}$ & $\begin{array}{l}1380,80 \\
\pm 262,08\end{array}$ & $\begin{array}{l}1325,75 \\
\pm 254,29\end{array}$ \\
\hline \multirow[t]{2}{*}{ PSRs } & $\begin{array}{l}\text { Correct answers } \\
\text { (\%) }\end{array}$ & $\begin{array}{l}84,21 \\
\pm 8,54\end{array}$ & $\begin{array}{c}73,42 \\
\pm 10,01 * * *\end{array}$ & $\begin{array}{l}85,25 \\
\pm 7,52\end{array}$ & $\begin{array}{r}78,75 \\
\pm 15,55 \text { * }\end{array}$ \\
\hline & $\begin{array}{l}\text { Latention } \\
\text { (ms) }\end{array}$ & $\begin{array}{l}1558,79 \\
\pm 428,23\end{array}$ & $\begin{array}{l}1653,79 \\
\pm 444,71\end{array}$ & $\begin{array}{l}1524,05 \\
\pm 342,89\end{array}$ & $\begin{array}{l}1481,65 \\
\pm 380,81\end{array}$ \\
\hline
\end{tabular}

$\mathrm{p}<0,05$ after vs. before

* $\mathrm{p}<0,01$ after vs. before

***: $\mathrm{p}<0,001$ after vs. before

\section{RESULTS}

Table 1 shows the anthropometric and ergometric characteristics of the subjects. Both groups were similar in all investigated features. No soldier showed any symptoms of heat exhaustion or other severe heat illness during or after EHST. All participants in the $\mathrm{C}$ group completed the tests, but 3 soldiers in the $\mathrm{H}$ group terminated tests between 60 and 85 minutes because of subjective intolerable strain or the reaching of the Tty limit. Figure 1 displays comparable reviews of Tty values during EHST. The mean Tty was significantly higher in the $\mathrm{H}$ group at the end of EHST (i.e., $90^{\text {th }}$ minute $)\left(39,5 \pm 0,16^{\circ} \mathrm{C}\right.$ vs. $36,78 \pm 0,11^{\circ} \mathrm{C}$ in the $\mathrm{C}$ group; $\mathrm{p}=0,0006$ ). The total increase in Tty values (average difference between Tty at the beginning and end of EHST) was also significantly higher in the $\mathrm{H}$ group $\left(1,56 \pm 0,26{ }^{\circ} \mathrm{C}\right.$ vs. $0,07 \pm 0,03{ }^{\circ} \mathrm{C}$ in the $\mathrm{C}$ group; $\left.\mathrm{p}=0,009\right)$. Figure 2 displays comparable reviews of HR values during EHST. Mean HR at the end of EHST was significantly higher in the H group $(148,90 \pm 5,90$ vs. $120,50 \pm 7,60 \mathrm{bpm} ; \mathrm{p}=0,0000)$. The limit of $180 \mathrm{bpm}$ was never reached, and the maximum recorded hart rate was $165 \mathrm{bpm}$. Table 2 summarises performance task means. There was a significant decrease in the percentage of correct answers in the $\mathrm{C}$ group in the MTS test after EHST $(88,64 \pm 6,95$ after EHST vs. 92,18 $\pm 5,14 \%$ before; $\mathrm{p}=0,038)$ and the PSRs test $(78,75 \pm 15,55$ vs. $85,25 \pm 7,52 \% ; \mathrm{p}=0,037)$. Decreases in the accuracy of both of these tests were more significant in the H group (MTS $84.31 \pm 9,51$ vs. $92,38 \pm 4,90 \%$ and PSRs $73,42 \pm 10,01$ vs. $84,21 \pm 8,54 \% ; \mathrm{ps}=0,002$ and 0,0006 , respectively). There was also a statistically significant decrease in performance in the RTI test in the $\mathrm{H}$ group. A decrease in the percentage of correct answers (93,89 $\pm 3,43$ vs. $95,74 \pm 3,52 \% ; \mathrm{p}=0,41)$ was accompanied by a significant increase in reaction time $(315,00 \pm 33,77$ vs. $300,32 \pm 31,53$ $\mathrm{ms} ; \mathrm{p}=0,048)$. There were no significant differences between responses for latency or number of errors before and after EHST in other tests, regardless of ambient conditions.

\section{DISCUSSION}

Heat strain impairs working efficiency and induces cognitive deficits. These abilities are particularly important in military services, where a dose-dependent relationship between heat stress and the number of errors in helicopter pilots is well established in laboratory and terrain conditions $(11,12)$. Banta and Braun also found that Navy helicopter pilots wearing individual cooling suits during the Gulf war to mitigate the detrimental effect of heat stress on cognition showed improved vigilance and accuracy (13). The possible beneficial effects of microclimate cooling were also of interest in the Army of Serbia. Jovanovic et al. demonstrated the efficiency of individual microclimate cooling systems based on phase-change materials, which alleviated the physical 
exertion caused by uncompensable heat stress $(8,9)$. They investigated male soldiers who performed EHST wearing impermeable protective suits and various types of microclimate cooling vests in a simulated environment (climatic chamber) and external conditions. They concluded that the use of cooling vests under protective suits during physical activity in hot conditions reduced sweating and alleviated heat stress, which was measured by increased core temperature and heart rate values. These cooling vest-induced physiological changes directly improved heat tolerance and hydration state, decreased the risk of heat illness, and extended the duration of soldiers' exposure to hot conditions. Dehydration itself profoundly influences cognitive performance (14), and the use of microclimate cooling systems may represent a promising solution to maintain vigilance and accuracy in soldiers exposed to heat stress.

Our results indicate that physical strain itself induced mild cognitive deficits, which was shown in the increased number of errors during the performance of complex tasks (i.e., MTS and the spatial part of the PSR test). These tests are designed to investigate working memory and sustained attention, and the latter test also investigates spatial orientation, which is a very specific and advanced function that is highly important in military services. The generally good performance of our soldiers in cool conditions is consistent with the results reported by other authors, who found that an acute boost of exercise may improve cognition (15). Mild deficits in our investigation may be caused by the longer duration and more strenuous physical activity compared to the study cited above.

The combination of the same intensity of physical strain and heat stress in our investigation led to more pronounced cognitive impairments in the same complex test, but it also imposed additional effect on attention, which are tested in the RTI. Soldiers in hot conditions showed a significant decrease in accuracy and a significant delay in reaction time in the RTI. The only function that was unaffected in this test was movement time. This mild cognitive deficit can likely be attributed to heat stress.

Hancock and Vasmatzidis stated in their review (16) that there are major difficulties in the interpretation of data on the influence of heat stress on cognitive functions. These difficulties are the consequences of various testing procedures, task demands and categorisation, duration of heat exposure, and subjects' skills and experience. These authors suggest that simple mental tasks show little, if any, decrements following heat exposure, and these tasks are frequently enhanced during brief exposures. However, substantial heat stress (30-33 ${ }^{\circ} \mathrm{C}$ WBGT) may lead to impairments in the performance of more complex tasks. The obtained results are consistent with the high WBGT $\left(29^{\circ} \mathrm{C}\right)$ in our trial.

Most of our subjects who performed tests in a hot environment suffered intensive physical strain, which was recorded by the high values of core temperature (up to $39,5^{\circ} \mathrm{C}$ ) and heart rates for a substantial time. However, these subjects did not show signs of serious cognitive deficits. Their relative resistance to heat exertion may be attributed to their high aero- bic capacity. This hypothesis is supported by the facts that some aspects of heat stress-induced cognitive impairment are explained by cerebral changes $(17,18)$, blood oxidative stress (19), and acute inflammatory reactions $(20,21)$. Several investigations $(22,23)$ confirmed that regular aerobic activity significantly induces beneficial adaptive effects on oxidative stress responses and inflammation parameters to acute exhausting endurance exercise in the heat, and our results may be interpreted from this point of view.

\section{CONCLUSIONS}

This study demonstrated the effects of strenuous physical activity in a hot environment on physiological parameters, which showed higher values of tympanic temperature and heart rate compared to cool conditions. This physiological heat stress enhanced the cognitive impairment caused by physical exertion itself. Performance deficits in a cool condition were mild and present only in complex tasks, but simpler tasks were relatively unaffected. Performance deficits in hot conditions were more pronounced and present in both complex and simpler tasks, such as reaction time.

\section{Acknowledgment}

This investigation was performed as a part of the MNTR 2011-2014, project TR 34034, which was financially supported by Ministry of Education, Science and Technological Development, Republic of Serbia.

\section{REFERENCES}

1. Amos D, Hansen R, Lau WM, Michalski JT: Physiological and cognitive performance of soldiers conducting routine patrol and reconnaissance operations in the tropics. Milit Med 2000; 165 (12): 961-6.

2. Radakovic SS, Maric J, Surbatovic M, Radjen S, Filipovic $\mathrm{N}$, Stefanova E, et al. Effects of acclimation on cognitive performance in soldiers during exertional heat stress. Milit Med 2007; 172 (2):190-5

3. Selkirk GA, McLellan TM. Influence of aerobic fitness and body fatness on tolerance to uncompensable heat stress. Appl Physiol 2001;91(5):2055-63

4. Labelle V, Bosquet L, Mekary S, Bherer L. Decline in executive control during acute bouts of exercise as a function of exercise intensity and fitness level. Brain Cognit 3001;81:10-7

5. Bandelow S, Maughan R, Shirreffs S, Ozgu K, Kurdak S, Erso G, et al. The effects of exercise, heat, cooling and rehydration strategies on cognitive function in football players. Scand J Med Sci Sports 2010;20(Suppl.3):148-60

6. ISO 12894 (E): Ergonomics of the thermal environment - Medical supervision of individuals exposed to extreme hot or cold environment. 2008 Sep, 
7. ISO 9886: Ergonomics evaluation of thermal strain by physiological measurements, 2008 Nov.

8. Jovanovic D, Karkalic R, Tomic Lj, Radakovic S, Velickovic Z. Experimental investigations in the microclimate body cooling systems based on phase change materials. Thermal Science 2014; DOI: 10.2298/TSCI130216129J

9. Jovanovic D, Karkalic R, Zeba S, Pavlovic M, Radakovic S. Physiological tolerance to uncompensated heat stress in soldiers: effects of various types of body cooling systems. Vojnosanit Pregl 2013; DOI: 10.2298/ VSP120731045D

10. Fray PJ, Robbins TW, and Sahakian BJ: Neuropsychiatric applications of CANTAB. Int J Geriat Psych 1996; 11: 329-36.

11. Faerevik H, Reinertsen RE: Effects of wearing aeircrew protective clothing on physiological and cognitive responses under various ambient conditions. Ergonomics 2003; 46(8): 780-99.

12. Froom P, Caine Y, Shochat I, Ribak J: Heat stress and helicopter pilot errors. J Occup Med 1993; 35: 720-4.

13. Banta GR, Braun DE. Heat strain during at-sea helicopter operations and the effect of passive microclimate cooling. Aviat Space Environ Med 1997;68:126-31

14. Cian C, Barraud PA, Melin B, Raphel C: Effects of fluid ingestion on cognitive function after heat stress or exercise-induced dehydration. Int J Psychophysiol 2001; 42: 243-51.

15. Tomporowski PD: Effects of acute bouts of exercise on cognition. Acta Physhol 2003; 112: 297-324.

16. Hancock PA, Vasmatzidis I: Effects of heat stress on cognitive performance: the current state of knowledge. Int J Hyperthermia 2003; 19(3): 355-72.
17. Nielsen B, Nybo L: Cerebral changes during exercise in the heat. Sports Med 2003; 33(1): 1-11.

18. Cheung SS, Sleivert GG: Multiple triggers for hyperthermic fatigue and exhaustion. Exerc Sport Sci Rev 2004; 32(3): 100-6.

19. Takahashi M, Suzuki K, Matoba H, Sakamoto S, Obara $S$. Effects of different intensities of endurance exercise on oxidative stress and antioxidant capacity. J Phys Fitness sports Med 2012;1:183-9

20. Quindry J, Miller L, McGinnis G, Kliszczewiscz B, Slivka D, Dunke C, et al. Environmental temperature and exercise-induced blood oxidative stress. Int J Sport Nutri Exerc Metab 2013;23:128-32

21. Mestre-Alfaro A, Ferrer MD, Banquells M, Riera J, Drobnic F, Sureda A, et al. Body temperature modulates the antioxidant and acute immune responses to exercise. Free Radic Res 2012;46:799-808

22. Shanely RA, Nieman DC, Henson DA, Jin F, Knab AM, Sha W. Inflammation and oxidative stress are lower in physically fit and active adults. Scand J Med Sci Sports 2013;23:215-23

23. Akhtari-Shojaei E, Jafari A, Namdar H, Farajov A, Khalili M. Comparison of inflammatory responses after acute moderate aerobic cycling in healthy young active and inactive men. Biomed Int 2011;2:64-71

24. Chase B, Karwowski W, Benedict ME, Quesada PM, Irwin-Chase HM. A study of computer-based task performance under thermal stress. Int J Occup Saf Ergon 2003; 9(1): 5-15.

25. Hancock PA, Williams G, Manning CM, Miyake S. Influence of task demand characteristics on workload and performance. Int J Aviat Psychol 1995; 5: 63-86. 